\title{
Hsp90 Inhibitor DS-2248
}

National Cancer Institute

\section{Source}

National Cancer Institute. Hsp90 Inhibitor DS-2248. NCI Thesaurus. Code C116851.

An orally active and small molecule inhibitor of heat shock protein 90 (Hsp90), with potential antineoplastic activity. Upon oral administration, Hsp90 inhibitor DS-2248 specifically blocks Hsp90, which inhibits its chaperone function and promotes the proteasomal degradation of oncogenic signaling proteins involved in tumor cell proliferation and survival. This may lead to an inhibition of tumor cell proliferation. Hsp90, a chaperone complex protein upregulated in a variety of tumor cell types, regulates the folding and degradation of many oncogenic signaling proteins. 